\title{
Deconstruction of Common-Sense Paradigm in Law Enforcement Against Corruption Crime
}

\author{
Deni Setya Bagus Yuherawan ${ }^{1}$ and Rocky Marbun ${ }^{2}$ \\ \{deniyuherawan@trunojoyo.ac.id ${ }^{1}$,rocky_marbun@univpancasila.ac.id $\left.{ }^{2}\right\}$ \\ Fakultas Hukum Universitas Trunojoyo Madura, Madura' ${ }^{1}$, Fakultas Hukum Universitas Pancasila, \\ Jagakarsa, Jakarta ${ }^{2}$
}

\begin{abstract}
Law enforcement against criminal acts that rests on the principle of premium remedium as stipulated in Law Number 31 of 1999 concerning Eradication of Corruption, which was most recently amended through Law Number 20 of 2001. As a result, this legal principle has become common sense in the process. law enforcement, so that axiologically, recovering state losses is not the goal of the law. However, imposing imprisonment is common sense. This study aims to reveal the existence of legal logic that is marginalized in the series of authoritative texts. The method used in this research is a normative juridical method using a deconstruction approach and a critical discourse analysis approach. The result of this research is an attempt to silence Article 14 in Law No. 31/1999 so that it is not implemented consistently and consistently.
\end{abstract}

Keywords: Deconstruction; Corruption; Common Sense; Law Enforcement

\section{Introduction}

Ideas or ideas from the principle of a rule of law accommodated in Article 1 paragraph (3) of the 1945 Constitution of the Republic of Indonesia (UUD NRI 1945), are not just carrying out law based on law alone. However, it is also based on respect for human rights and based on the authority that becomes juridical legitimacy in enforcing the law. As explained by FJ. Stahl who explained that the rule of law principle consists of (a) elements based on human rights; (b) elements of respect for human rights; (c) elements of governance based on statute/law; and (d) elements of administrative justice as a control against deviation from respect for human rights.[1]

Referring to the rule of law principle, the state establishes two types of general policies, namely policies on social life and policies on state life. Where, in the policy of state life, a demand arises for the state in designing and formulating legislation not only based on knowledge of legal history, sources of law, or the organization of law enforcement institutions ansich. However, it is also based on how it is applied and the mystical atmosphere when the legislative process takes place, as well as the timeliness (temporality) of the legal product [2].

When we talk about "how is it applied?", Of course, here we will intersect with the concept of law enforcement. And when, in contact with the 'mystical atmosphere in the legislative process', then we are discussing the historical interpretation regarding the basic intentions of the legislation. Meanwhile, when it comes to the 'timeliness (temporality) of a legal product, we are discussing the dynamics of legislation based on needs. 
In this study, the researcher tries to fuse the horizon (point of view) based on these concepts against the object of study in this study, namely the criminal act of corruption with Derrida's Deconstruction Theory. The thought departs from an assumption when a law enforcement process against perpetrators of corruption has become common sense it always ends in imprisonment.

According to Romli Atmasasmita, the phenomenon of law enforcement against corruption in Indonesia has 3 (three) problems, namely (1). Overuse of criminalization, (2). Overuse of prosecution, and (3). Overuse of imprisonment [3]. At the level of the overuse of criminalization, there is an expansion in the formulation of legal norms against corruption. So, the result is the overuse of persecution and leads to the overuse of imprisonment. Thus, there is a neglect of the teleological element of law enforcement against criminal acts of corruption.

Based on data from the International Corruption Watch (ICW), from 2015 to 2018, 1,087 people have been named suspects in corruption cases with a total state financial loss of Rp. 5.6 trillion, the number of bribes of Rp. 134.7 billion, the number of illegal levies amounting to Rp. 6.7 billion, and the amount of money laundering amounting to Rp. 91 billion [4], which occurred in the natural resources, public services, governance, and social sectors [4]. In fact, in 2019, through the 2019 State Budget DIPA, the KPK has set a target of 109 cases [5]. However, in 2019, the KPK has named 155 people as suspects from 62 cases. Meanwhile, the Police handled 100 cases with 209 people as suspects, and the AGO handled 109 cases with 216 people as suspects [5].

If we refer to the explanation from Romli Atmasasmita, between the prosecution that resulted in a suspect and a convict, it is not directly proportional to operational costs especially by the KPK. So, of course, it should be questioned again regarding the pattern of legal interpretation of legal events that are suspected of being criminal acts of corruption based on the initial intentions of the legislators of Law No. 31 of 1999 in conjunction with Law no. 20 of 2001. Therefore, the interpretation model that has been used at this time has an impact on the occurrence of overcriminalization which is the result of the overuse of criminalization.

Therefore, this article explores the following research questions; How is the commonsense paradigm reversed so that it is in line with criminal law politics in general concerning the national legal system?

\section{Research Method}

This study uses the Normative Juridical Method which examines library materials or secondary legal materials as the basic material to be researched through the search of statutory regulations and literature related to the issues under study [6]. This study uses several types of approaches, namely the conceptual approach, the case approach, and the philosophical approach. The analysis model used is a qualitative analysis based on in-depth understanding (in-depth analysis) to reveal the meaning contained in each variable that intersects the problem under study. 


\section{Jacques Derrida: The Deconstructionist}

Jacques Derrida or better known as 'Derrida', is a French philosopher, who was born in 1930 in El Bair near Al Jazair and is of Jewish descent from both of his parents [7]. As a philosopher, Derrida did not escape the influence of his predecessors, such as Husserl, Ferdinand de Saussure, Nietsczhe, and Martin Heiddeger as well as several philosophers who belonged to the modern era, such as Immanuel Kant, Hegel, and even returned to the era of Aristotle's thought.

Based on the originality of Derrida's criticism of logocentric, one of the aspects that will be used as one of the analysis tools in this research is Derrida's study of Binary Opposition in Language aimed at criticizing Ferdinand de Saussure. However, in general, to understand Derrida's version of deconstruction, refer to the views of McQuillan by mentioning five steps, namely: [8]

a. Deconstruction is not a means or method but an event of reading. There are no set rules, criteria, procedures, programs and sequence of steps and theories to be followed in deconstruction;

b. Deconstruction involves the contamination of binary oppositions, pairs of opposite meanings;

c. Deconstruction is interested in marginalization and instability;

d. Deconstruction is history, therefore, the term favored in binary opposition occurs in history;

e. Deconstruction does not distinguish between text and context because what is called context does not exist outside the text, but is already in the text and can be accessed within the text.

Deconstruction challenges the centralized mode of meaning and tends to be rounded as what the text might want or that is deliberately brought out clearly by the logical relationship of the text. When applying deconstructive reading, it becomes clear that the "inexpressible" strength of the text does not always coincide with the dominant reading. That power is logic that is belittled as a secondary meaning, logic which at times endangers the construction of the text or produces ambiguous paradoxes, which undermine the dominant reading. The logic of the game shaped by deconstructive reading shows that a text can refute something it emphasizes, although often that denial is implicit and vague. The denial which tries to be hidden by one dominant reading makes the meaning no longer singular, but plural and widens in another direction, into telos that can no longer be controlled [9].

This opposition to linguistics goes hand in hand with the same in the western philosophical tradition. In this binary opposition, according to the western philosophical tradition, the terms of the former employer are superior to those of the second subordinate/employee. The second terms are false representations of the first or are inferior. This tradition is called logocentrism and is used to explain the assumption of privileges that the first term and "abuse" of the second term bears [10].

The Binary Opposition concept, according to Rocky Marbun [11], is an attempt by Derrida to dismantle the metaphysics of presence as a "myth" in modernity which is a legacy of western philosophy. Derrida tries to show the existence of a false consciousness contained in the metaphysics of that presence, as something that is' common sense ', and tries to shake that awareness with the premise that there is another meaning that is removed as something' other 'in its wholeness with the meaning' the central one '.

Another way to deconstruct is to use key deconstruction ideas. Through these key ideas, the hierarchical relations between elements in the text systematically contaminate each other. 
In other words, the destabilization process of the text structure occurs in this process. The text is in crisis. At that moment of crisis, "other logic" or "new" elements are displayed which cannot be returned to the previous hierarchical relationship. The crisis in the perspective of deconstruction means more opportunities for the emergence of "other" than chaos. "Other logic" or "new" elements, must come from material and economic sources in the text itself. Metaphorically, the reading is like a parasite eating from the flesh of the text while spawning critical matters in the text [12].

Referring to the above explanation, the binary opposition which occupies a position as 'the other' and is seen as a parasite, for Derrida is a text that must be allowed to speak out to contaminate other dominant texts. Thus, the false consciousness in the metaphysics of presence is shaken by the emergence of other texts that were not previously taken into account with the context of their emergence. However, Derrida's deconstruction does not mean eliminating the existing meaning

\section{Soerjono Soekanto's Law Enforcement Theory}

According to Soerjono Soekanto [13] that what is meant by "law enforcement" is a process that focuses on activities to harmonize the relationship of values that are outlined in solid and embodied principles and attitudes as a series of defining the final stage of values, to create, and maintain peace social life. So, it is not wrong when Soerjono Soekanto [13] argues that the use of power and authority in the law enforcement process, in essence, cannot be released by the use of discretion by law enforcement officials in interpreting and implementing the established legal rules.

Soerjono Soekanto's opinion received doctrinal strengthening from Sudikno Mertokusumo[14] who emphasized that through law enforcement, the law becomes a reality. In upholding the law, three elements must always be considered, namely legal certainty (rechtssicherheit), benefit (zweckmassigkeit), and justice (gerechtigkeit). He [15] further stated that if in upholding the law only legal certainty is concerned, then other elements are sacrificed, and vice versa.

Soerjono Soekanto's viewpoint - related to law enforcement, is indeed driven by a sociological, not normative, approach. This can be seen from his explanation of the meaning of the concept of law enforcement that he promotes, namely "harmonizing the relationship of values in a solid rule". Where, he further explained that in law enforcement, these pairs of values need to be harmonized, namely between the value of the order and the value of peace. This is because the value of order starts on attachment, while the value of peace starts on freedom. However, these values need a more concrete explanation, because the usual values are abstract, namely in the form of rules. According to Soerjono Soekanto [15], these rules contained orders, prohibitions, or permissions. So, what is meant by rule is a legal norm or statute. The term rule is a word in a social context, while the term norm is a word in a normative legal context.

The view mentioned above is essentially Soerjono Soekanto's criticism of the discourse on legal phenomena that has occurred so far. According to Soerjono Soekanto, if you want to talk about legal phenomena in all its aspects, like it or not, you must also mention the society that is the legal container. Soerjono Soekanto realized that his views were unusual with the thinking at that time because Indonesia followed the flow of the continental European legal tradition. Where in the Continental European tradition, the law is seen as something that is 
value-free. So, according to Soerjono Soekanto [16], it is rather difficult to be able to analyze the phenomenon of the law as an element of the whole life relationship. This means, that more interdisciplinary approaches will be applied so that problems that cannot be solved by law alone can be explored from other social science angles.

In the development of legal science in general and legal practice, according to Soerjono Soekanto [17], problems often arise concerning the correctness of legal principles and the effectiveness of these legal principles. This is because, the problem of formulating the correct rule of law is a problem of legal dogmatics (normative law science), while the effectiveness of a law is a problem of the sociology of law and other social sciences. This is one of the disturbances to the law enforcement process, due to a different paradigm in looking at the law. Although in fact, Soerjono Soekanto himself carried out the same distribution.

Further explained by Soerjono Soekanto [13], that interference with law enforcement may occur, if there is a mismatch between the trinity in the form of values, rules, and behavior patterns. The disturbance occurs when the mismatch between paired values, which are incompatible with conflicting principles, and undirected behavior patterns that disturb the peace of life. Although, Soerjono Soekanto [13] also emphasized that the pattern of behavior in law enforcement does not merely mean the implementation of legislation.

Based on the foregoing, according to Soerjono Soekanto [13], a law enforcement process is influenced by several factors, namely:

\section{The legal factor, namely law.}

According to Soerjono Soekanto [13], this legal factor is interpreted as law in the sense that material is a written regulation that is generally accepted and made by the central government or regional governments. However, sometimes within the law itself, there are several problems. The problem exemplified by Soerjono Soekanto, for example, is the existence of Article 284 paragraph (1) of the Criminal Procedure Code which states the following:

"Concerning cases that existed before the promulgation of this law, as far as possible the provisions of this law will be enforced."

As for the explanation of Article 284 paragraph (1) of the Criminal Procedure Code states "Self-explanatory". According to Soerjono Soekanto [13], Article 284 paragraph (1) of the Criminal Procedure Code opens up the possibility to deviate from the principle that the law is not retroactive. Another problem expressed by Soerjono Soekanto [13] was the existence of various laws that did not yet have implementing regulations, even though these laws were ordered to do so.

The third problem raised by Soerjono Soekanto [13] was the ambiguity in the words used in the formulation of certain articles. Perhaps this is due to the use of words whose meanings can be interpreted in a very broad way, or because of translation problems from foreign languages. Thus, the legal factor here is an obstacle to the law enforcement process, if there are:
a. Disobedience to legal principles;
b. Absence of implementing regulations; and
c. Editorial vagueness.

Law enforcement factors, namely the parties who form and implement the law.

The explanation from Soerjono Soekanto regarding the law enforcement factor above is interesting to examine. Therefore, he separated the parties who formed the law and those who 
applied the law. Where he firmly classifies elements of law enforcement as those implementing the law by taking the example of the Police.

According to him [13], the average citizen has the hope that the police can immediately overcome the problems they are facing regardless of whether the police have just graduated from police education, or are experienced policemen. The award goes to the police who have the lowest rank to the highest rank. The people who deal with the police, do not have the chance to think about the level of education experienced by the lowest ranking police. Where in dealing with these problems, some require immediate action, but there are also problems that only then require action, if not prevented.

So, according to Soerjono Soekanto [13], assessing the decision to immediately take action or postpone taking action is a discretion-based role issue. Therefore, discretion is concerned with decision-making that is not strictly bound by law, where personal judgment also plays a role. In law enforcement, discretion plays an important role, because:

a. There is no law that is so complete that it can regulate all human behavior;

b. There are obstacles to adjusting legislation with developments in society, causing uncertainty;

c. Lack of costs to implement legislation as legislators want; and

d. There are individual cases that require special handling.

One aspect that Soerjono Soekanto also discussed was related to "mainstreaming material values". Even though in his view, if it is interpreted grammatically-lexically it is aimed at society, if it is examined historically, it relates to the mentality of the law enforcer. Soerjono Soekanto [16] explained that the emphasis on material values makes it very difficult for good law enforcement, because in dealing with procedures that have been regulated by law, usually there is an intention to deviate from it by giving money as a lubricant. The giving of facilitation payments is certainly not an independent act, but there must be a reciprocal relationship with the Investigator. If, a good Police investigator, of course, will reject the facilitation payment, so that it does not hinder good law enforcement. On the subject of this discussion, a hermeneutical circle emerges between understanding discretion well and understanding the role of law enforcers well.

One example of the results of the hermeneutical circle above is the use of discretion because of a consideration, as long as the events do not disturb order and peace, do not commit acts of force [17]. Usually, it is done to groups of teenagers who disturb the order by using the action of dissolving or in complaint offenses where crimes in the family are committed, they tend not to take certain actions in the form of arrests.

In connection with the dialectical relationship between the use of discretion and the perspective of this role, according to Soerjono Soekanto, when viewed from a juridicalphilosophical point of view, healthy and fair legal relationships in the police function should fulfill certain basic values. These basic values are always paired and are the antinomies that must always be harmonized. That is, the basic values are a pair of values; a particular value will not be possible to be replaced with another value, because that value must always be harmonized with the values that are its pair. Thus, if a value develops, the value of its partner decreases, and vice versa [17].

\section{Facilities and facilities that support law enforcement.}

According to Soerjono Soekanto [13], without certain facilities or facilities, law enforcement can't proceed smoothly. These facilities and facilities include, among other things, educated and skilled human resources, good organization, adequate equipment, sufficient finance, and so on. If these things are not fulfilled, it is unlikely that law 
enforcement will achieve its objectives. According to Soerjono Soekanto [17], the limited facilities and facilities will lead to the use of discretion to overcome these limitations.

However, Soerjono Soekanto provides the following limitations:

a. This discretion must always be returned to the police function in dealing with real events, where he must have between his function as a law enforcement officer or as a peace officer;

b. The police must consider whether the events at hand disturb public order and private order proportionally or not; and

c. It is necessary to consider the response of community members to the police function, namely whether there is a good or bad image; in the use of discretion.

Community factors, namely the environment in which the law applies or is applied.

In reality, you can find various forms of legal action or behavior. An attitude of legal action or behavior usually has a certain effect, when it is related to the behavior of other parties. An attitude of the other party's actions towards the desired goal; means if the other party obeys the law [17]. However, there is a strong tendency in society to obey the law out of fear of being subject to negative sanctions if the law is violated. One negative effect is that the law will not be obeyed if no one is closely monitoring its implementation. Where the rules are not closely monitored, there is an opportunity to bypass them [16].

Thus, it can also be said that one of the effects of law is disobedience to the law. Thus, the problem of legal influence is not only limited to the emergence of legal obedience or compliance but includes the total effect of the law on attitudes of behavior, both positive and negative (meaning in the form of compliance or non-compliance) [17].

Cultural factors, namely as a result of creative works, and feelings that rely on the human initiative in social life.

Soerjono Soekanto deliberately distinguishes between cultural factors and social factors, because according to him, the issue of value systems which is the core of spiritual or nonmaterial culture is highlighted in his discussion. Further explained by Soerjono Soekanto [13], following the division of elements of the legal system from Lawrence M. Freidman, that legal culture (system) includes the values that underlie applicable law, values which are abstract conceptions of what is considered good (so that it is followed) and what is considered bad (so that it is avoided). These values are usually pairs of values that reflect two extreme conditions that must be harmonized.

Then Soerjono Soekanto [17] provided a basis in the form of a philosophical foundation for the process of matching these value pairs, namely:

a. Pair the value of freedom with the value of the order.

b. Pair the value of legal flexibility with the value of lawfulness.

c. Pair of legal comparability value with legal certainty value.

d. Pair the difference value with the similarity value.

e. Pair career interest values with service interests.

f. Pair material values with moral values.

An imbalance in one of the factors may result in the whole system being negatively affected. According to Soerjono Soekanto, if the written law that regulates a field of life is too rigid or not flexible, then the entire system of that field of life (and other related fields) will proceed in an imbalance. So, all levels of society will feel the bitter consequences. So, according to Soerjono Soekanto [16], the factors mentioned above are factors inherent in the human being, who may occupy various positions in society, and also carry out several roles. 


\section{Interpreting the Legal System in the Corruption Crime Law Enforcement Process}

Researchers try to refer to the meaning of the legal system, by moving from the views of Bagir Manan and Sudikno Mertokusumo to explain what Soerjono Soekanto meant. Where, according to Bagir Manan, that every statutory regulation has natural defects and artificial defects, where this is a consequence of a form of written law which results in the regulation having a limited reach - just taking the moment from the political, economic, social, cultural and security elements that were most influential at the time of its formation because it is very easy to "out of date" when compared to changes in society that are getting faster and accelerated [18]. However, long before that, Sudikno Mertosukumo [15] also explained, "When we talk about law in general, we only look at legal regulations in terms of laws or regulations, especially practitioners.

Laws are imperfect; indeed, it is impossible for them to completely regulate all activities of human life. Sometimes the law is incomplete and sometimes the law is not clear. Even though it is incomplete and unclear, the law must be implemented. " So that a discrepancy is created between das sollen and das sein. Why is there a discrepancy? Why did Sudikno Metokusumo say that a law can be classified as vague and incomplete? And why did Bagir Manan call it the Law carrying congenital and artificial defects?

Jimly Asshiddiqie [19] explained that norms or rules (rules) are the institutionalizations of good and bad values in the form of rules that contain permissions, recommendations, or orders. Both recommendations and orders can contain positive or negative rules so that they include norms of advice to do or suggestions not to do something, and norms of orders to do or orders not to do something. He [19] further explained that the rule of law can also be distinguished between general and abstract norms and concrete and individual norms. General rules are always abstract because they are addressed to all related subjects without designating or relating them to specific concrete subjects, parties, or individuals.

These general and abstract legal rules are usually the material for legal regulations that apply to any person or anyone subject to the formulation of legal principles contained in the relevant laws and regulations. It is in this case that an interpretation becomes very important. Thus, the method of legal discovery, for example, interpretation, is an attempt to converge between abstract and general legal norms on concrete problems. Therefore, the development of society always goes beyond laws and regulations [20].

Based on the above views, it is true that what Soerjono Soekanto expressed, in law enforcement, the position of discretion is very important. Therefore, the discretion contains patterns of behavior of law enforcement officers in interpreting and finding laws regarding concrete facts of society. Soerjono Soekanto [16] also expressed the same thing as the legal experts' description above but used a social language that was not well understood by followers of normative law science. He explained that human behavior may be a part of the natural motion that is bound by the law of cause and effect. Likewise with certain behavior from a legal point of view is called legal behavior.

However, as an element of the natural state, human behavior is not the object of legal understanding. That is, what determines a behavior is a legal symptom or not, or whether a behavior deviates or does not deviate from the law, is not determined by natural considerations. To determine all of these, there are what are called norms or rules, especially the rule of law, which is both an interpretive framework and a framework for judgment. Regarding the interpretive framework and assessment framework, according to the researcher, 
it is more appropriate when looking at the views of Jimly Asshiddiqie [21] which explains that interpretation is a method to understand the meaning contained in legal texts to be used to solve cases or make decisions on matters faced concretely. In the context of law enforcement, the Investigator is the authority that in carrying out investigative examinations at the PreAdjudication stage will always make interpretations and legal findings to determine - at least, on two things, namely whether or not there is a suspected criminal incident and is it appropriate or inappropriate to use the articles to make someone a suspect?

According to Johnny Ibrahim [22], legal discovery (rechtsvinding) is not an independent activity, but one that is coherent and continuous with evidentiary activities. Meanwhile, concerning the process of interpretation and legal discovery in the process of law enforcement, according to Polak, the method of interpretation is determined by the material of the legislation concerned, the place where the case was filed, and according to the era [23]. This means that law enforcement as a process of alignment between values, rules, and behavior cannot be a patterned or mechanical activity.

Against such law enforcement, it becomes relevant to what was stated by E. Utrecht [24] who emphasized that there is a relationship between each legal regulation. A rule of law does not stand alone. Every rule of law has its place in the legal field. The place becomes a certain place, this is the result or consequence of interdependency (interconnected) of each social phenomenon. Several legal regulations that contain several equations in the form of the same elements or aim to achieve the same object are a certain set of rules, which is known as "an interconnected internally" (innerlijke samenhang).

Thus, the meaning of these phrases implies that departing from social phenomena that exist in human life, raises the result of various regulations on certain social phenomena. Where these arrangements, because they originate from several social phenomena, it is very likely that these regulations intersect with each other. If we pay attention to the descriptions mentioned above, in essence, the things put forward by E. Utrecht are following the concept of timeliness (temporality) from Padmo Wahyono. Also, Padmo Wahyono's expression about 'how to apply' correlates with the views of Soerjono Soekanto who studied law enforcement, which essentially requires the ability to interpret which is manifested in the discretionary action of every law enforcer in interpreting a series of laws.

When we draw these views into the law enforcement process against corruption, the existence of Law no. 31 of 1999 in conjunction with Law no. 20 of 2001 is not in a vacuum. Therefore, the State correlates it with several laws which start from the silence of Article 14 of Law no. 31 of 1999 which affirms "Every person who violates the provisions of the Law which expressly states that a violation of the provisions of the Law is a criminal act of corruption shall apply the provisions regulated in this Law."

To understand the meaning of Article 14 of Law no. 31 of 1999, it is necessary to further investigate the 'norm addressat' (target norms) -in other words, the subject who manages the objects and objects that are regulated, namely state finances, civil servants-which are expanded, and their management system. Thus, law enforcement efforts require the ability to distill through the interpretation of legislation relating to subjects and objects regulated in Law No. 31 of 1999. If the study is directed at the norm address in the form of Civil Servants, then there is Law Number 28 of 1999 concerning the Implementation of a State that is Clean and Free from Corruption, Collusion and Nepotism, Law Number 5 of 2014 concerning State Civil Servants, and Law Number 30 of 2014 concerning Government Administration. These three laws have two regulatory focuses, namely Civil Servants as the norm address and the accountability system. 
If the study is directed at the object of Law no. 31 of 1999 in conjunction with Law no. 20 of 2001, namely state finances, so there is Law Number 17 of 2003 concerning State Finance, and Law Number 1 of 2004 concerning State Treasury. Both laws have a focus on the state financial management system. The intercorrelation between the norm address and the state financial management system is contained in Article 14 of Law no. 31 of 1999, so, it can be concluded that Law no. 31 of 1999 in conjunction with Law no. 20 of 2001 is a model of secondary legal norms, while a series of other laws are models of primary legal norms.

However, the role of law enforcement institutions in the law enforcement process is often fixed on the editorial of the articles which are interpreted rigidly. The authority granted in the realm of State Administrative Law (SAL) to the Investigator and Public Prosecutor as well as in the realm of judicial power in the judiciary cannot be utilized optimally. The pattern of thinking that is patterned based on the legal positivism view, to shape the behavior of law enforcers in understanding the law, is carried out linearly, deterministically, and mechanically [25]. As a result, legal certainty is only interpreted linearly by ignoring the legal principles contained in a series of laws.

Thus, Article 14 of Law no. 31 of 1999 in conjunction with Law no. 20 of 2001, through this linear thinking pattern is the binary opposition of "the other" which is marginalized and has no voice in the process of law enforcement against corruption. Therefore, thinking positivistic has become common sense in law enforcement.

\section{Conclusion}

Reversal of the meaning of Article 14 of Law no. 31 of 1999 in conjunction with Law no. 20 of 2001 is not intended to erase the current meaning as common sense, however, it is an attempt at binary contamination of 'the central'. Thus, enriching the way of thinking based on systematic interpretation through a series of legislation on norm addresses — including the system of accountability for positions and the system for managing state finances.

So, through this binary contamination effort, it will reduce the behavior of overuse of criminalization, overuse of prosecution, and overuse imprisonment in the criminal law system in Indonesia against law enforcement for alleged corruption.

\section{Acknowledgements}

Researchers are very grateful to those who have helped to materialize this research. The researchers' gratitude goes to the Dean of the Faculty of Law, Trunojoyo University, Madura, and the Dean of the Faculty of Law, Pancasila University.

\section{References}

[1] Wahyono, P. Membudayakan Undang-Undang Dasar 1945, Jakarta: Ind-HILL.co, pp. 73 (1991).

[2] Wahyono, P. Indonesia Negara Berdasarkan Atas Hukum. Jakarta: Ghalias Indonesia, pp. 17-18 (1986).

[3] Atmasasmita, R. Korupsi Pandemik - Bansos, Makalah dipresentasikan pada Webinar dengan tema "Korupsi Bantuan Sosial" yang diselenggarakan oleh Masyarakat Hukum Pidana dan Kriminologi Indonesia (MAHUPIKI), pada tanggal 27 Juli 2020, pp. 12-13 (2020).

[4] Alamsyah, W., Abid, L., dan Sunaryanto, A. Laporan Tren Penindakan Kasus Korupsi Tahun 2018, Jakarta: International Corruption Watch (ICW), pp. 4 (2018) 
[5] International Corruption Watch (ICW). Laporan Tren Penindakan Kasus Korupsi 2019, Jakarta: ICW, pp. 26 (2019).

[6] Soekanto, S., dan Mamudji, S. (2001). Penelitian Hukum Normatif (Suatu Tinjauan Singkat), Jakarta: Rajawali Press, h. 13-14.

[7] Turiman. (2015). Metode Semiotika Hukum Jacques Derrida: Membongkar Lambang Negara Indonesia, Jurnal Hukum dan Pembangunan, 44(2), h. 309.

[8] Hardiman, F.B. (2015). Seni Memahami. Yogyakarta: Kanisius, h. 278-282.

[9] Ariwidodo, E. (2013). Logosentrisme Jacques Derrida Dalam Filsafat Bahasa, Jurnal Karsa, 21(2), h. 345-346. DOI: http://dx.doi.org/10.19105/karsa.v21i2.38

[10] Norris, C. (2016). Membongkar Teori Dekonstruksi Jacques Derrida, Yogyakarta: Ar-Ruzz Media, h. 9.

[11] Marbun, R. (2020). Pasivitas Fungsi Advokat Dalam Proses Pra-Adjudikasi: Membongkar Tindakan Komunikatif Instrumental Penyidik. Jurnal Hukum Samudra Keadilan, 15(1), h. 24.

[12] Ungkang, M. (2013). Dekonstruksi Jacques Derrida Sebagai Strategi Pembacaan Teks Sastra. Jurnal Pendidikan Humaniora, 1(1), h. 34-35.

[13] Soekanto, S. (2014). Faktor-faktor Yang Mempengaruhi Penegakkan Hukum, Jakarta: RajaGrafindo Persada, h. 5

[14] Mertokusumo, S. (2002). Mengenai Hukum. Suatu Pengantar, Yogyakarta: Liberty, h. 145.

[15] Mertokusumo, S. dan Pitlo, A. (1993). Bab-bab Tentang Penemuan Hukum, Citra Adtya Bakti, Yogyakarta, h. 2.

[16] Soekanto, S. (1983). Penegakan Hukum, Jakarta: Binacipta, h. 1

[17] Soekanto, S. (1988). Efektivitas Hukum Dan Peranan Sanksi, Bandung: Remadja Karya, h. 1-2.

[18] Ridwan. (2014). Diskresi \& Tanggung Jawab Pemerintah, Yogyakarta: FH UII Press, h. 5.

[19] Asshiddiqie, J. (2006). Perihal Undang-Undang, Jakarta: Konstitusi Press, h. 1.

[20] Sibuea, H.P. (2011). Asas Negara Hukum, Peraturan Kebijakan \& Asas-Asas Umum Pemerintahan Yang Baik, Jakarta: Erlangga, h. 69-70 dan h. 63-64.

[21] Asshiddiqie, J. (2006). Pengantar Ilmu Hukum Tata Negara. Jilid I, Jakarta: Sekretariat Jendral dan Kepaniteraan Mahkamah Konstitusi Republik Indonesia, h. 273.

[22] Ibrahim, J. (2007). Teori \& Metodologi Penelitian Hukum Normatif, Malang: Bayumedia Publishing, h. 219.

[23] Nurdin, B. (2012). Kedudukan dan Fungsi Hakim Dalam Penegakan Hukum di Indonesia, Bandung: Alumni, h. 99.

[24] Utrecht, E. dan Djindang, M.S. (1989). Pengantar Dalam Hukum Indonesia, Jakarta: Pustaka Sinar Harapan, h. 212.

[25] Putro, W.D. (2011). Kritik Terhadap Paradigma Positivisme Hukum, Yogyakarta: Genta Publishing, h. 5. 